\title{
Implementasi Fungsi Manajemen dalam Pelayanan Bimbingan Manasik Haji di Kelompok Bimbingan Ibadah Haji
}

\author{
Iseu Susilawati*, Ahmad Sarbini, \& Asep Iwan Setiawan \\ Jurusan Manajemen Dakwah, Fakultas Dakwah dan Komunikasi, \\ UIN Sunan Gunung Djati, Bandung \\ *Email: iseususilawati@student.uinsgd.ac.id
}

\begin{abstract}
ABSTRAK
Penelitian ini bertujuan untuk mengetahui bagaimana implementasi fungsi manajemen di Kelompok Bimbingan Ibadah Haji (KBIH) Bustanul Wildan dalam pelayanan bimbingan manasik haji, untuk mengetahui upaya yang dilakukan oleh Kelompok Bimbingan Ibadah Haji (KBIH) Bustanul Wildan dalam pelayanan bimbingan manasik haji, dan untuk mengetahui faktor pendukung dan faktor penghambat bimbingan manasik haji di Kelompok Bimbingan Ibadah Haji (KBIH) Bustanul Wildan. Metode penelitian yang digunakan adalah metode kualitatif dengan pengumpulan data secara deskriptif yang bertujuan untuk menggambarkan, memaparkan, dan menjelaskan data-data mengenai manajemen pelayanan pada KBIH Bustanul Wildan dalam meningkatkan kualitas calon jamaah haji dan umrah yaitu melalui wawancara, observasi, studi dokumentasi kepada objek penelitian tersebut. Dari hasil temuan penelitian ini dapat diketahui bahwa implementasi fungsi manajemen dalam pelayanan yang diberikan oleh KBIH Bustanul Wildan terhadap tingkat kualitas calon jamaah terdiri dari fungsi manajemen, yang terdiri dari perencanaa, pengorganisasian, pelaksanaan dan evaluasi. Upaya yang dilakukan KBIH Bustanul Wildan dalam melayani jamaah yaitu dengan cara melayani setiap calon jamaah haji dalam pengurusan semua administrasi yang berkaitan dengan pelaksanaan ibadah haji dan umroh, berusaha terbuka dalam setiap proses pendaftaran haji dengan cara mempertemukan jamaah dengan bank, memberikan bimbingan manasik. Selain itu, KBIH Bustanul Wildan tidak terlepas dari faktor pendukung dan faktor penghambat dalam melayani calon jamaah haji.
\end{abstract}

Kata Kunci: Implementasi; Fungsi Manajemen; Pelayanan Manasik

\section{ABSTRACT}

The purpose of this research is to know how the implementation of management function in Bustanul Wildan Haij Guidance Group (KBIH) Bustanul Wildan in guidance service of Haij manasik, to know the effort done by Bustanul Wildan Hajj Guidance Group (KBIH) Bustanul Wildan in guidance service of Hajj manasik, and to know factor advocates and inbibiting factors of hajj pilgrimage in the Hijrah Guidance Group (KBIH) Bustanul Wildan. The research method used is qualitative method with descriptive data collection aimed to describe, describe, and 
Implementasi Fungsi Manajemen dan Pelayanan Manasik ...

explain data about service management at KBIH Bustanul Wildan in improving the quality of hajj and umrah candidates through interview, observation, documentation study to the object of research the. From the findings of this study it can be seen that the implementation of management functions in services provided by KBIH Bustanul Wildan to the quality level of candidates have met the needs of prospective pilgrims by applying management functions, which consists of perencanaa, organizing, implementation and evaluation efforts made KBIH Bustanul Wildan in serving the pilgrims is by serving every candidate pilgrims in the administration of all administration related to the implementation of pilgrimage and umroh, trying to open in every process of hajj registration by meeting together with the bank, providing guidance manasik. KBIH Bustanul Wildan can not be separated from supporting factors and inbibiting factors as much as possible listening to the complaints of prospective pilgrims for the inconvenience when before haij and after hajj.

Keywords: Implementation; Management Functions; Manasik Service

\section{PENDAHULUAN}

Islam adalah agama dakwah, yaitu agama yang menugaskan umatnya untuk menyebarkan dan menyiarkan islam kepada seluruh umat manusia. Sebagai suatu rahmat bagi seluruh alam yang ada, islam dapat menjamin terwujudnya suatu kebahagiaan dan kesejahteraan bagi seluruh umat manusia, bilamana agama islam ini mencakup segenap aspek kehidupan itu dijadikan sebagai pedoman hidup dan dilaksanakan secara sungguh-sungguh oleh umat manusia (Shaleh, 1986:1). Agar tujuan dakwah dapat tercapai dengan bai, maka komponen serta unsur-unsur dakwah secara baik dan tepat (Fatoni, 2014). Adapun salah satu komponen serta unsur dakwah yang dimaksud adalah media dakwah, dalam hal ini salah satu media dakwah yang paling utama terkait haji adalah Kelompok Bimbingan Ibadah Haji (KBIH).

Semua agama menjunjung tinggi kebebasan komunikasi dan informasi diantara umat manusia. Bahkan Allah memerintahkan manusia selalu berkomunikasi dengan-Nya, memohon ampunan-Nya, ridho-Nya, perlindunganNya, dan petunjuk-Nya merupakan sebuah informasi dari manusia kepada TuhanNya (Muis, 2001:180). Salah satu bentuk komunikasi manusia kepada Tuhannya adalah dengan melakukan ritual ibadah haji. Dengan melakukan ritual ibadah haji merupakan sarana untuk mengungkapkan rasa syukur atas nikmat yang telah Allah berikan kepada manusia.

Haji pada hakikatnya merupakan sarana dan media bagi umat islam untuk melaksanakan ibadah ke Baitullah dan tanah suci. Karena setiap tahun sebagian kaum muslimin dari seluruh dunia datang untuk menunaikan ibadah haji (Muis, 2001:21).

Setiap umat muslim menginginkan terciptanya kesempurnaan dalam beribadah dengan menjalankan perintah-perintah Allah dan menjauhi segala larangan-Nya, Al-Quran dan Al-Hadits adalah pegangan bagi umat muslim yang didalamnya terdapat perintah dan larangan yang harus dijalankan oleh umat muslim salah satunya adalah rukun islam dan rukun iman menjadi amalan yang 
Iseu Susilawati, Ahmad Sarbini, \& Asep Iwan Setiawan

harus dilaksanakan. Rukun islam ada lima, dan menunaikan ibadah haji adalah salah satu dari kelima rukun tersebut. Telah dijelaskan pula dalam Al-Quran surah Ali'Imran ayat 97 :

Artinya: "Padanya terdapat tanda-tanda yang nyata, (diantaranya) maqam Ibrahim barangsiapa memasukinya (Baitullah itu) menjadi amanah dia; mengerjakan haji adalah kewajiban manusia terhadap Allah, Yaitu (bagi) orang yang sanggup mengadakan perjalanan ke Baitullah. Barangsiapa mengingkari (kewajiban haji), maka sesungguhnya Allah Maha Kaya (tidak memerlukan sesuatu) dari semesta alam".

Ibadah haji merupakan rukun Islam kelima yang wajib dilaksanakan oleh setiap orang Islam yang memenuhi syarat istitah, baik secara finansial, fisik, maupun mental. Negara bertanggung jawab atas penyelenggaraan ibadah haji sebagaimana yang diamanatkan dalam Pasal 29 Ayat (2) Undang-Undang Dasar Negara Republik Indonesia Tahun 1945, yang menyatakan bahwa Negara menjamin kemerdekaan tiap-tiap penduduk untuk memeluk agamanya masingmasing dan untuk beribadat menurut agama dan kepercayaannnya itu. Indonesia sebagai salah satu negara yang memiliki jumlah penduduk beragama Islam terbesar di dunia, melakukan penyelenggaraan ibadah haji setiap tahunnya. Saat ini dasar dan payung hukum pelaksanaan penyelenggaraan ibadah haji pada UndangUndang Nomor 13 Tahun 2008 Tentang Penyelenggaraan Ibadah Haji.

Dalam Undang-Undang Nomor 13 Tahun 2008 tentang Penyelenggaraan Ibadah Haji, mengatur mengenai rangkaian kegiatan pengelolaan pelaksanaan ibadah haji yang meliputi pembinaan, pelayanan, dan perlindungan jamaah haji. Adapun tujuan penyelenggaraan ibadah haji yaitu untuk memberikan pembinaan, pelayanan, dan perlindungan yang sebaik-baiknya bagi jamaah haji sehingga jamaah haji dapat menunaikan ibadahnya sesuai dengan ketentuan ajaran agama Islam. Penyelenggaraan ibadah haji dilaksanakan berdasarkan asas keadilan, profesionalitas, dan akuntabilitas dengan prinsip nirlaba. Di dalam mewujudkan kesejahteraan rakyat diperlukannya pelayanan yang seoptimal mungkin kepada masyarakat, partisipasi aktif dari masyarakat luas juga membantu terwujudnya pelayanan yang lebih baik. Maka aparatur pemerintah harus lebih mampu dan tanggap dalam memberikan pelayanan diberbagai bidang dan sektor. Kemampuan dan tanggapan ini dapat diperoleh dengan cara menyederhanakan prosedur dan tata cara pelayanan. Sehingga masyarakat yang membutuhkan pelayanan merasakan adanya kemudahan, kelancaran, dan kepastian.

Dengan adanya pelayanan yang baik dan seoptimal mungkin diharapkan dapat mencapai tujuan pembangunan nasional, yakni mewujudkan masyarakat madani yang taat hukum, berperadaban modern, demokratis, adil, makmur, dan bermoral tinggi, maka diperlukan pegawai negeri yang merupakan unsur aparatur negara yang bertugas sebagai abdi masyarakat yang harus melaksanakan pelayanan secara adil dan merata kepada masyarakat dengan dilandasi kesetiaan dan ketaatan kepada Pancasila dan Undang-Undang Dasar 1945.

Kelompok Bimbingan Ibadah Haji (KBIH) merupakan lembaga sosial islam 
yang bergerak dalam bidang Bimbingan Manasik Haji terhadap calon jamaah haji baik selama pembekalan di tanah air maupun pada saat ibadah haji di tanah suci. Kelompok Bimbingan Ibadah Haji $(\mathrm{KBIH})$ sebagai lembaga sosial keagamaan (non pemerintah) merupakan sebuah lembaga yang telah memiliki legalitas pembimbingan melalui Undang-Undang dan lebih diperjelas melalui sebuah/wadah khusus dalam struktur baru Departemen Agama dengan Subsit Bina KBIH pada Direktorat Pembinaan Haji (Buku Pedoman Pembinaan KBIH, 2006:1).

Kelompok Bimbingan Ibadah Haji (KBIH) yang bergerak dibidang penyelenggraan haji sangatlah berepran dalam mengurus, mengelola, melaksanakan dan mengatur serangkaian kegiatan yang telah direncanakan sebelumnya. Terutama dalam melayani para calon jamaah haji, pelayanan itu terbentuk sebagai upaya aparatur pemerintah (pegawai negeri) untuk mengefektifkan kegiatan atau pelayanannya sesuai dengan kondisi para calon jamaah atau lingkungan yang dilayani, yang bagaimana sekalipun keadaannya.

Kelompok Bimbingan Ibadah Haji (KBIH) Bustanul Wildan adalah salah satu lembaga yang bergerak dibidang jasa pelatihan, bimbingan dan pemberangkatan jamaah haji dan umrah yang bertujuan untuk membimbing dan mencoba membantu melancarkan pelaksanaan ibadah haji dan umrah di indonesia yang selama ini kurang dalam segi pelayanan. Dimana pelayanan tersebut juga harus sesuai standar pelayanan haji yang telah diatur oleh undang-undang tentang ibadah haji dan umrah. Kelompok Bimbingan Ibadah Haji (KBIH) Bustanul Wildan menerapkan prinsip kerja berdasarkan fungsi-fungsi manajemen yang meliputi: perencanaan, pengorganisasian, pelaksanaan, dan pengawasan. Penulis menjadikan Kelompok Bimbingan Ibadah Haji (KBIH) Bustanul Wildan sebagai obyek penelitian karena lembaga tersebut menerapkan manajemen yang berorientasi pada peningkatan mutu pelayanan, dan untuk mengetahui bagaimana Kelompok Bimbingan Ibadah Haji (KBIH) Bustanul Wildan melayani para calon jamaah dalam melaksanakan ibadah haji dan umrah.

Penelitian ini dilakukan pada Kelompok Bimbingan Ibadah Haji (KBIH) Bustanul Wildan yang beralamat di Jl. Raya Cileunyi No. 18 A Bandung Jawa Barat. Alasannya masalah ini sangat penting untuk dipecahkan karena berkaitan dengan implementasi fungsi manajemen pelayanan dalam meningkatkan kualitas jamaah haji. Lokasi ini relatif mudah terjangkau dari tempat tinggal peneliti, yang memungkinkan efektivitas dan efisiensi dalam pengumpulan data-data dan informasi yang dibutuhkan.

Untuk pertanyaan penelitian yang diajukan terhadap masalah yang diangkat yaitu berhubungan dengan implementasi fungsi manajemen, upaya yang dilakukan, dan faktor pendukung dan penghambat dalam pelayanan bimbingan manasik haji di Kelompok Bimbingan Ibadah Haji (KBIH) Bustanul Wildan. 
Iseu Susilawati, Ahmad Sarbini, \& Asep Iwan Setiawan

\section{LANDASAN TEORITIS}

Dalam penelitian ini teori yang digunakan adalah teori G.R. Terry (Hasibuan, 2001:38), yaitu fungsi manajemen yang terdiri dari perencanaan (planning), pengorganisasian (organizing), pelaksanaan (actuating) dan evaluasi (controlling).

Implementasi berasal dari implementation yang berarti pelaksanaan dan penerapan dari sebuah teori (Chols dkk, 1996: 313). Sedangkan menurut Van Meter dan Van Horn dikutip oleh Wahab (1990: 51), implementasi adalah tindakan-tindakan yang dilakukan oleh individu-individu, pejabat-pejabat, atau kelompok-kelompok pemerintah atau swasta pada tercapainya tujuan-tujuan yang telah digariskan ada keputusan kebijaksanaan. Sedangkan menurut Susilo (2007:174) Implementasi merupakan suatu penerapan ide, konsep, kebijakan atau inovasi dalam suatu tindakan praktis sehingga memberikan dampak baik berupa perubahan pengetahuan, keterampilan maupun nilai dan sikap.

Menurut George R. Terry (Brantas, 2009), manajemen merupakan sebuah subjek yang sangat penting karena ia mempersoalkan penetapan serta pencapaian tujuan-tujuan. Manajemen tidak saja mengidentifikasikan, menganalisis dan mengkombinasikan secara efektif bakat orang-orang dan mendayagunakan sumber-sumber tersebut kadang-kadang dinyatakan enam M dari manajemen, yaitu (1) Men, Tenaga kerja manusia, baik tenaga kerja eksekutif maupun operatif; (2) Money, Uang yang dibutuhkan untuk mencapai tujuan yang diinginkan; (3) Methods, Cara-cara yang dipergunakan dalam usaha mencapai tujuan; (4) Machines, Mesin-mesin atau alat-alat yang diperlukan/dipergunakan untuk mencapai tujuan; (6) Markets, Pasar untuk menjual output dan jasa-jasa yang dihasilkan. Sumbersumber tersebut dipersatukan dan ditetapkan secara harmonis sedemikian rupa. Sehingga tujuan yang telah ditetapkan dapat tercapai dengan ketentuan bahwa segala sesuatu berlangsung dalam batas-batas waktu, usaha, serta biaya yang ditetapkan.

Terry mendefinisikan manajemen dalam bukunya Principles of Manajement yaitu: "suatu proses yang membedakan atas perencanaan, pengorganisasian, penggerakan dan pengawasan dengan memanfaatkan baik ilmu maupun seni demi mencapai tujuan yang telah ditetapkan sebelumnya". Dari definisi Terry itulah kita bisa melihat fungsi manajemen menurutnya. Berikut ini adalah fungsi manajemen menurut Terry: a) Perencanaan (Planning) yaitu sebagai dasar pemkiran dari tujuan dan penyusunan langkah-langkah yang akan dipakai untuk mencapai tujuan; b) Pengorganisasian (Organizing) yaitu sebagai cara untuk mengumpulkan orangorang dan menempatkan mereka menurut kemampuan dan keahliannya dalam pekerjaan yang sudah direncanakan; c) Penggerakan (actuating) yaitu untuk menggerakan organisasi agar berjalan sesuai dengan pembagian kerja masingmasing serta menggerakan seluruh sumber daya yang ada dalam organisasi agar pekerjaan atau kegiatan yang dilakukan bisa berjalan sesuai rencana dan bisa mencapai tujuan; d) Pengawasan (controling) yaitu untuk mengawasi apakah gerakan dari organisasi ini sudah sesuai dengan rencana atau belum. Serta mengawasi penggunaan sumber daya dalam organisasi agar bisa terpakai secara efektif dan 
efisien tanpa ada yang melenceng dari rencana. Adapun Manajemen secara istilah dikemukakan oleh beberapa ahli diantaranya, Badrudin (2013:2),menyebutkan bahwa manajemen merupakan disiplin ilmu yang bertugas mencari kebenaran dalam predikat dimensi teoritis dan metodologi yang harus diuji dan dibuktikan berdasarkan fakta/data secara objektif kebenarannya.

Menurut Manullang (1972: 1), yang dimaksud dengan manajemen pada umumnya definisi yang lajim diberikan kepada management adalah The art of getting thing done through the effort of other people ialah definisi yang diberikan oleh Newman dan Terry yang mengatakan bahwa management adalah fungsi yang berhubungan dengan memperoleh hasil tertentu melalui orang lain. Dalam Encyclopedia of the social science maka management itu dibatasi "Manajemen adalah proses dengan mana pelaksanaan dari pada suatu tujuan tertentu diselenggarakan dan di awasi".

Manajemen adalah ilmu dan seni mengatur proses pemanfaatan sumber daya manusia dan sumber-sumber lainnya secara efektif dan efisien untuk mencapai suatu tujuan tertentu. Adapula yang menyatakan bahwa manajemen merupakan kekuatan yang menjalankan sebuah kekuatan yang menjalankan sebuah perusahaan dan yang bertanggungjawab atas keberhasilan dan kegagalannya (Hasibuan, 2002: 1-2).

Definisi lain menyatakan bahwa manajemen adalah pemuasan kebutuhankebutuhan ekonomi dan sosial karena bersifat produktif bagi manusia, bagi perekonomian dan bagi masyarakat. Manajemen mencakup kegiatan untuk mencapai tujuan, dilakukan oleh individu-individu yang menyumbangkan upayanya yang terbaik melalui tindakan-tindakan yang telah ditetapkan sebelumnya. Hal tersebut meliputi pengetahuan tentang apa yang harus mereka lakukan, menetapkan bagaimana mereka harus melakukannya dan mengukur dari efektivitas usaha-usaha mereka. Sselanjutnya perlu menetapkan dan memelihara pula suatu kondisi lingkungan yang memberikan responsi ekonomis, psikologis, sosial, politis dan sumbangan-sumbangan teknis serta pengendaliannya. Manajemen merupakan sebuah kegiatan; pelaksanaannya disebut managing dan orang yang melakukannya disebut manager (Terry, 1990: 6).

Perencanaan merupakan usaha sadar dan pengambilan keputusan yang telah diperhitungkan dengan matang tentang hal-hal yang akan dikerjakan dimasa depan dalam dan oleh suatu organisasi dalam rangka pencapaian tujuan yang telah ditentukan sebelumnya (Siagian, 1989:50). Didalam buku Pengantar Ilmu Manajemen (Kadarman dan Udaya, 1994:47), bahwa perencanaan mempunyai empat tujuan penting, yaitu: 1) Mengurangi dan mengimbangi ketidakpastian dan perubahanperubahan di waktu yang akan datang; 2) Memusatkan perhatian kepada sasaran; 3) Mendapatkan atau menjamin proses pencapaian tujuan; 4) Memudahkan pengawasan. Semua fungsi lainnya sangat bergantung pada fungsi ini, dimana fungsi ini tidak akan berhasil tanpa perencanaan dan pembuatan keputusan yang tepat dan cermat. Tetapi sebaliknya perencanaan yang baik tergantung dari pelaksanaan efektif terhadap fungsi-fungsi ini (Handoko, 1991:24).

Pengorganisasian merupakan keseluruhan proses pengelompokan orang- 
Iseu Susilawati, Ahmad Sarbini, \& Asep Iwan Setiawan

orang, alat-alat, tugas-tugas serta wewenang dan tanggung jawab sedemikian rupa sehingga tercipta suatu organisasi yang dapat digerakkan sebagai suatu kesatuan yang utuh dan bulat dalam rangka pencapaian tujuan yang telah ditetapkan sebelumnya (Fadli, 2002:30).

Fungsi penggerakan merupakan fungsi manajerial yang amat penting, karena secara langsung berkaitan dengan manusia, dengan segala jenis dan kebutuhannya. Pentingnya unsur manusia jelas sekali terlihat dalam seluruh proses administrasi dan manajemen (Siagian, 1989:128). Tujuan organisasi yang telah ditetapkan untuk dicapai pada akhirnya haruslah dalam rangka peningkatan mutu hidup manusia. Untuk itu sangat dibutuhkan sekali peran seorang manajer, seorang manajer harus mempunyai keterampilan berkomunikasi secara efektif.Karena, peranan komunikasi sangat besar dalam mendorong motivasi yang kuat dalam diri anggota organisasi untuk berkarya lebih giat dan tekun ( Choliq, 2011:257).

Tentang pengertian pelayanan para ahli mengemukakan pendapatnya yang berbeda-beda satu sama lain. Diantara para ahli yang mengemukakan pendapat tentang pelayanan yaitu sebagai berikut: 1) Menurut Philip Kottler, "Pelayanan dapat diartikan sebagai suatu aktivitas yang bermanfaat yang diberikan oleh satu atau beberapa pihak kepada pihak lain untuk dapat memuaskan kebutuhan dan keinginan yang pada dasarnya bersifat baik terwujud dan tidak akan menimbulkan kepemilikan apapun kepada yang menerimanya (Kottler, 1994:446); 2) Menurut H. N. Casson, mendefinisikan pelayanan sebagai tindakan-tindakan yang dinyatakan atau dikerjakan untuk menyenangkan, memberi petunjuk atau memberi keuntungan kepada pembeli dengan tujuan atau menciptakan goodwill atau nama baik serta meningkatkan penjualan serta pendapat (Casson, 1981:93).

Untuk mencapai kecepatan dan ketepatan pelayanan yang akan diberikan, pelayanan yang baik juga perlu didukung oleh ketersediaan dan kelengkapan produk yang dibutuhkan pelanggan (Kasmir, 2006:31-32). Sedangkan menurut Tom Peters (2004:32), seorang pakar manajemen dalam bukunya Mohammad Iqbal mengatakan bahwa untuk memberikan pelayanan yang baik perusahaan harus dekat dengan pelanggan atau "close to the customer", artinya secara terus menerus mendengar apa yang dikatakan pelanggan dan secara teratur mengukur kepuasan pelanggan. Pelayanan yang baik akan tergambar dari kepuasan yang dirasakan seorang pelanggan, demikian pula sebaliknya.

Haji secara bahasa berasal dari bahasa Arab حَجُْجَجَّ yang kemudian diterjemahkan ke dalam bahasa Indonesia menjadi haji (KH. Abdib Bisri, 1999:100). Haji dapat diartikan sebagai mengunjungi, menuju, dan ziarah. Secara istilah haji adalah berkunjung ke baitullah ( $\mathrm{Ka}$ 'bah) untuk melakukan beberapa amalan, antara lain : wukuf, thawaf, sa'I dan amalan lainnya pada masa tertentu demi memenuhi panggilan Allah SWT dan mengharapkan ridha-Nya (Edi Mulyono dan Harun Abu Rofi'ie, 2013:15). 


\section{HASIL DAN PEMBAHASAN}

Untuk mencapai hasil yang memuaskan dalam suatu lembaga, maka diperlukan kerja yang sungguh-sungguh serta berdasarkan peraturan.Hal ini merupakan syarat mutlak untuk mencapai tujuan bersama dalam memberikan pelayanan yang baik sesuai dengan standar operasional pelayanan (SOP).Dan juga didasari dengan manajemen yang baik, oleh karena itu perananan manajemen sangat diperlukan.

KBIH Bustanul Wildan merupakan mitra kerja pemerintah dalam hal memberikan bimbingan ibadah haji bagi calon jamaah haji.Kegiatan yang dilaksanakan oleh KBIH Bustanul Wildan menggunakan fung-fungsi manajemen agar mampu dalam mencapai tujuan yang ditetapkan KBIH Bustanul Wildan.

Lembaga KBIH Bustanul Wildan mempunyai tujuan dan orientasi dalam meningkatkan pelayanan ibadah haji kedepannya lebih baik agar mencapai tujuan efektif dan efisien tidak lepas dari keberadaan manajemen.Untuk mencapai tujuan yang diharapkan, maka KBIH Bustanul Wildan menggunakan peranan fungsi manajemen dalam mengelola semua aktivitas pelayanan ibadah haji di KBIH Bustanul Wildan agar berjalan dengan baik.

Adapun menurut Terry (Hasibuan, 2001:38) untuk menentukan dan mencapai tujuan-tujuan organisasi dapat dilakukan dengan pelaksanaan fungsifungsi perencanaan (Planning), pengorganisasian (Organizing), penggerakan (Actuating), dan pengawasan (Controling).

Dalam melaksanakan bimbingannya Kelompok Bimbingan Ibadah Haji (KBIH) Bustanul Wildan Kabupaten Bandung selalu menerapkan fungsi-fungsi manajemen dalam setiap pengelolaannya agar bisa mencapai tujuan yang telah diterapkan secara efektif dan efisien.Berikut adalah implementasi fungsi-fungsi manajemen pada Kelompok Bimbingan Ibadah Haji (KBIH) Bustanul Wildan Kabupaten Bandung.

Dalam melaksanakan kegiatan ibadah haji dan umrah, KBIH Bustanul Wildan mengimplementasikan fungsi manajemen sesuai dengan teori dari G.R Terry. Hal ini dikemukakan oleh salah-satu narasumber Rafidah Nurfauziah (wawancara, 07 Mei 2017) selaku staff KBIH Bustanul Wildan yang menyatakan bahwa: "KBIH Bustanul Wildan untuk menentukan dan mencapai tujuan-tujuan organisasi dilakukan dengan pelaksanaan fungsi-fungsi sebagai berikut: perencanaan (planning), pengorganisasian (organizing), penggerakan (actuating), dan pengawasan (controlling).

\section{Implementasi Fungsi Manajemen dalam Pelayanan Bimbingan Manasik Haji di KBIH Bustanul Wildan}

Berikut ini adalah implementasi fungsi manajemen yang digunakan dalam pelayanan bimbingan manasik haji di KBIH Bustanul Wildan : 1) fungsi perencanaan : suatu kegiatan jika diawali dengan perencanaan yang matang, maka akan memberikan hasil yang bagus bagi organisasi tersebut. Fungsi perencanaan harus diterapkan, karena dengan perencanaan yang memungkinkan sehingga tepat dan sesuai dengan kondisi yang dialami pada saat itu.

Bimbingan manasik haji KBIH Bustanul Wildan idealnya sebuah 
organisasi yang menginginkan organisasinya berjalan maksimal dan mencapai tujuan secara optimal. Untuk mencapai tujuan secara maksimal dan optimal tersebut, organisasi membutuhkan manajemen.Berbicara tentang manajemen tidak lepas dari pembicaraan tentang fungsi-fungsi manajemen. Fungsi manajemen yang pertama kali harus diterapkan adalah perencanaan. Karena perencanaan merupakan sebuah tindakan untuk menentukan atau merancang tindakan yang harus dilakukan pada masa yang akan datang, apabila sebuah organisasi tidak mempunyai perencanaan itu artinya organisasi tersebut tidak memiliki tujuan/orientasi. Perencanaan terjadi di semua tipe kegiatan. Perencanaan adalah proses dasar dimana manajemen memutuskan tujuan dan cara mencapainya. Perbedaan pelaksanaan adalah hasil tipe dan tingkat perencanaan yang berbeda pula. Perencanaan dalam organisasi adalah esensial, karena dalam kenyataan

nya perencanaan memegang peranan lebih disbanding fungsi-fungsi manajemen lainnya.

Kelompok Bimbingan Ibadah Haji (KBIH) Bustanul Wildan di dalam penyelenggaraan ibadah haji selalu menerapkan fungsi-fungsi manajemen, karena KBIH Bustanul Wildan menginginkan organisasi berjalan maksimal dan mencapai tujuan secara optimal. Dalam penerapan fungsi manajemen, KBIH Bustanul Wildan selalu mempertimbangkan aturan yang ada, penerapan fungsi manajemen yang dilakukan pertama kali adalah perencanaan, karena perencanaan merupakan fungsi manajemen yang paling esensial dan juga perencanaan memegang peranan penting dibandingkan fungsi-fungsi manajemen lainnya.

Adapun perencanaan yang dibuat oleh KBIH Bustanul Wildan antara lain perencanaan bimbingan di tanah air (sebelum berangkat ibadah haji), perencanaan bimbingan di Arab Saudi (pelaksanaan ibadah haji), dan juga perencanaan bimbingan di tanah air (pasca ibadah haji). Sebelum manajer dapat mengorganisasikan, mengarahkan atau mengawasi, mereka harus membuat rencana yang memberikan tujuan dan arah organisasi. Dalam perencanaan, manajer memutuskan "apa yang harus dilakukan, kapan melakukannya, dan siapa yang melakukannya”. Jadi, Perencanaan merupakan usaha sadar dan pengambilan keputusan yang telah diperhitungkan dengan matang tentang hal-hal yang akan dikerjakan dimasa depan dalam dan oleh suatu organisasi dalam rangka pencapaian tujuan yang telah ditentukan sebelumnya (Siagian, 1989:50).

Adapun program yang disediakan oleh KBIH Bustanul Wildan dalam perencanaan adalah sebagai berikut: 1) Bimbingan di Tanah air (Sebelum Ibadah Haji) Salah satu bentuk perencanaan sebelum keberangkatan ibadah haji di KBIH Bustanul Wildan ialah adanya jadwal bimbingan selama di tanah air; 2) Bimbingan di Tanah Suci, Jamaah haji yang mengikuti bimbingan di KBIH Bustanul Wildan tidak hanya mendapatkan pendampingan dan bimbingan di tanah air saja, tetapi juga mendapatkan bimbingan dan pendampingan pada saat menjalankan ibadah haji di tanah suci.untuk itu KBIH Bustanul Wildan selalu mengirimkan pengurus sebagai petugas haji, untuk membina dan mendampingi jamaah haji. Selama proses pelaksanaan ibadah haji berlangsung, pendamping dan Pembina yang bertugas dan 
juga jamaah haji yang dirasa lebih mampu membantu jamaah yang kurang mampu atau lemah. Sehingga Pembina dan pendamping yang bertugas akan lebih mudah menjalankan tugasnya. Untuk mempermudah proses bimbingan dan pendampingan di tanah suci, pengurus menerapkan sistem kebersamaan, kekeluargaan dan saling tolong menolong. Demi kelancaran proses bimbingan sampai pelaksanaan ibadah haji, tentunya perlu adanya jadwal rencana kegiatan yang harus dibuat, sehingga proses bimbingan di tanah air sampai pelaksanaan ibadah haji di tanah suci bisa berjalan secara sistematis.

Selain itu, dengan adanya jadwal tersebut akan mempermudah berlangsungnya bimbingan sampai pelaksanaan ibadah haji, bahkan sampai jamaah haji tiba di tanah air lagi; 3) Bimbingan di Tanah Air (Pasca Ibadah Haji), KBIH Bustanul Wildan tidak hanya memberikan bimbingan dan pendampingan di tanah air sampai di tanah suci saja.Tetapi juga memberikan bimbingan dan pendampingan pasca ibadah haji.Kegiatan tersebut dilaksanakan dengan tujuan untuk lebih mendekatkan diri kepada Allah dan menjaga kemabruran haji selain itu juga untuk mempererat silaturahmi antar jamaah haji KBIH Bustanul Wildan.Kegiatan tersebut dilakukan setiap hari minggu bertempat di madrasah KBIH Bustanul Wildan. Perencanaan yang telah dibuat oleh pengurus KBIH Bustanul Wildan tidak hanya sebatas rencana saja, tetapi oleh pengurus rencana tersebut diimplementasikan, meskipun dalam tahapan implementasi tidak semuanya sesuai dengan perencanaan yang telah dibuat, karena perencanaan yang dibuat kadang tidak sesuai dengan situasi dan kondisi yang dihadapi, sehingga perencanaan yang dibuat mengalami modifikasi atau perencanaan kembali sesuai dengan kebutuhan.

Jadi, berdasarkan dari data di atas bahwa KBIH Bustanul Wildan dalam menyelenggarakan bimbingan ibadah haji sudah menerapkan fungsi perencanaan. Implementasi fungsi perencanaan yang dilakukan oleh $\mathrm{KBIH}$ Bustanul Wildan sudah sesuai dengan teori yang dikemukakan oleh G.R Terry bahwa perencanaan berarti menentukan sebelumnya apa yang harus dilakukan dan bagaimana cara melakukannya. Meskipun dalam tahapan implementasi kadang tidak sesuai dengan perencanaan yang telah dibuat (Handayaningrat, 1983:25). Hal itu dikarenakan pengurus KBIH Bustanul Wildan selalu mempertimbangkan faktor kebutuhan sesuai dengan situasi dan kondisi yang ada.Setiap perencanaan yang dilakukan tidak selamanya tepat, sudah bisa dipastikan adanya kendalaatau terjadinya hal-hal yang tidak sesuai dengan perencanaan, tergantung bagaimana pengurus menyikapi hal tersebut. Pengurus KBIH Bustanul Wildan selalu tanggap dengan persoalan tersebut, terbukti pengurus selalu mengadakan modifikasi atau perencanaan kembali apabila perencanaan awal dalam tahap implementasi kurang tepat. 2) fungsi pengorganisasian : agar tujuan KBIH Bustanul Wildan dapat tercapai, maka dibentuk organisasi untuk mengelompokan dan membagi tugas sesuai dengan kemampuan masing-masing.Maka dalam rangka mencapai tujuan KBIH Bustanul Wildan membentuk struktur organisasi untuk menjalankan seluruh kegiatan yang telah direncanakan. Namun terkadang struktur yang dibentuk tidak berjalan sesuai 
Iseu Susilawati, Ahmad Sarbini, \& Asep Iwan Setiawan

dengan tugasnya masing-masing, karena pimpinan menjalankan tugasnya sendiri tanpa meminta bantuan kepada stafnya.

Kepengurusan KBIH Bustanul Wildan kurang bisa berjalan dengan maksimal.Bentuk dari kurang maksimalnya kepengurusan adalah pengurus kurang bisa melaksanakan job discriptionnya dengan maksimal. Meski demikian KBIH Bustanul Wildan masih tetap eksis, karena pimpinan di KBIH tersebut sangat memperjuangkan untuk mempertahankan keberadaan $\mathrm{KBIH}$ Bustanul Wildan dan juga pimpinan KBIH mempunya kharismatik tersendiri sehingga jamaah untuk mengikuti bimbingan manasik di KBIH Bustanul Wildan.

Dalam pengorganisasian pihak KBIH Bustanul Wildan telah mengelompokkan atau membagi tugas kepada para staff $\mathrm{KBIH}$ Bustanul Wildan itu sendiri, dan ditugaskan untuk mengatasi masalah-masalah yang ada pada KBIH Bustanul Wildan, baikitu masalah pelayanan kepada para calon jamaah haji dan umrah, masalah pelaksanaan ketika pendaftaran, transportasi, akomodasi, konsumsi, dan masalah kesehatan.

Pihak KBIH Bustanul Wildan telah memilih para staff atau pekerja yang benar-benar dapat bertanggungjawab dan dipercaya atas tugasnya tersebut. Sehingga para calon jamaah tidak kebingungan dalam melaksanakan ibadah haji dan umrah selain itu juga, agar terciptanya jamaah haji dan umrah yang mabrur dan sesuai dengan sunnah rasul. 3)Fungsi Penggerakan : sebuah perencanaan tidak akan tercapai tanpa adanya implementasi. Oleh karena itu, ketika sebuah organisasi menginginkan hasil yang maksimal perlu adanya implementasi dari perencanaan yang telah ditetapkan, sehingga apa yang menjadi tujuan akan benar-benar tercapai. Demi terealisasinya program-program yang telah ditetapkan bersama, semua program KBIH Bustanul Wildan bekerja sama dan berusaha semaksimal mungkin dalam mengimple.mentasikan program-program yang telah direncanakan. Dalam pelaksanaan bimbingan di tanah air (sebelum berangkat) sampai bimbingan di tanah suci (pelaksanaan ibadah haji) semuanya hampir berjalan sesuai dengan perencanaan yang telah dibuat.

Untuk sistem penyelenggaraan ibadah haji terdiri atas aspek kelembagaan, manajemen, pengelolaan keuangan, peningkatan dalam pengebangan sumber daya manusia, serta dukungan sarana dan prasarana yang efektif dalam memberikan pelayanan kepada para calon jamaah haji dan umrah, paling tidak ada maslah yang teridentifikasi seperti pendaftaran, biaya, bimbingan, pelayanan kesehatan,dan lain sebagainya. 4) Fungsi Pengawasan : dalam melakukan pengawasan KBIH Bustanul Wildan membaginya ke dalam empat bagian, pertama yaitu pasca perekrutan. Setelah melakukan perekrutan, pengurus mengkaji kembali kekurangan dan kelebihan dari proses perekrutan tersebut agar dapat menjadi acuan untuk perekrutan sebelumnya yang lebih baik agar jumlah jamaah yang mengikuti bimbingan di KBIH Bustanul Wildan semakin meningkat kedepannya. Sistem evaluasi yang digunakan adalah dengan menggunakan metode musyawarah dan diskusi bersama. Kedua yaitu pengawasan/evaluasi pada saat pasca penyelenggaraan bimbingan, baik bimbingan pada saat ditanah air (pembekalan), 
bimbingan di tanah suci (pelaksanaan) maupun bimbingan di tanah air (pasca ibadah haji).

Sistem pengawasan/evaluasi yang dilakukan oleh pengurus terhadap proses bimbingan menggunakan metode wawancara, yakni pengurus mengambil salah seorang jamaah untuk dijadikan sampling untuk dimintai keterangan terkait dengan bimbingan dan pelayanan yang telah diberikan oleh pengurus kepada jamaah. Dengan adanya evaluasi/pengawasan tersebut, diharapkan agar pengurus atau pembimbing mengetahui kemapuan dari para jamaahnya. Adapun hal-hal yang dievaluasi antara lain; apakah jamaah bimbingan KBIH Bustanul Wildan sudah memahami dan menguasai materi bimbingan, sejauh mana jamaah mampu mengaplikasikannya, dan sejauh mana tingkat kepuasan jamaah terhadap pelayanan yang diberikan oleh pengurus KBIH Bustanul Wildan. Selama proses ibadah haji berlangsung, Pembina dan pendamping setiap saat selalu melakukan koordinasi dan evaluasi. Baik berupa koordinasi dan evaluasi internal Pembina dan pendamping, juga mengadakan koordinasi dan evaluasi dengan jamaah bimbingan KBIH Bustanul Wildan. Ketiga pada saat di tanh suci, koordinasi dan evaluasi lebih sering dilakukan, agar segala persoalan yang muncul terkait dengan jamaah haji yang dipandu KBIH Bustanul Wildan dapat segera terselesaikan. Dengan adanya koordinasi dan evaluasi tersebut diharapkan ibadah haji yang dilakukan oleh jamaah haji mencapai kesempurnaan dan tercapailah haji yang mabrur. Keempat evaluasi juga dilakukan oleh pengurus di tanah air pasca penyelenggaraan haji. Evaluasi ini dilakukan dengan tujuan untuk mengetahui segala kekurangan maupun kelebihan pada saat penyelenggaraan ibadah haji selama satu periode. Dengan adanya evaluasi ini diharapkan solusi yang dihasilkan terhadap kajian penyelenggaraan ibadah haji periode ini dapat dikembangkan dan dilaksanakan pada periode kedepan sehingga periode kedepan benar-benar lebih sukses dari periode ini.Jadi, dapat ditarik kesimpulan bahwa, KBIH Bustanul Wildan di dalam menjalankan organisasi juga sudah menerapkan fungsi pengawasan/evaluasi sesuai dengan teori GR. Terry tentang evaluasi/pengawasan (Hasibuan, 2001:41).

\section{Upaya-upaya yang dilakukan dalam Pelayanan kepada Jamaah}

Adapun upaya-upaya yang dilakukan oleh KBIH Bustanul Wildan untuk melayani calon jamaah haji diantaranya: 1) Melayani setiap calon jamaah haji dalam pengurusan semua administrasi yang berkaitan dengan pelaksanaan ibadah haji dan umroh. Dalam menjalankan kegiatannya tentu saja KBIH Bustanul Wildan banyak berhubungan dengan publik, terutama para jamaah. Sebagaimana yang telah dikemukakan oleh H. N. Casson, bahwa pelayanan sebagai tindakantindakan yang dinyatakan atau dikerjakan untuk menyenangkan, memberi petunjuk atau memberi keuntungan kepada pembeli dengan tujuan atau menciptakan goodwill atau nama baik serta meningkatkan penjualan serta pendapat (Casson, 1981:93).

Karena pada dasarnya suatu perusahaan atau lembaga harus dapat menjalin hubungan yang baik dengan publiknya, karena pada dasarnya keberadaan suatu lembaga atau perusahaan tidak akan terlepas dari perhatian masyarakat atau 
publik, khususnya dalam hal ini adalah para calon jamaah haji. Menjalin hubungan dengan para calon jamaah haji dititik beratkan pada perwujudan hubungan yang harmonis serta diiringi dengan hubungan yang baik antara pihak pengelola KBIH Bustanul Wildan dengan jamaahnya sebagai pengguna jasa KBIH Bustanul Wildan.Hal tersebut bertujuan agar tercipta kepercayaan, pengertian dan kerjasama antara kedua belah pihak.

Hubungan yang baik dan harmonis sangat penting dijalankan oleh $\mathrm{KBIH}$ Bustanul Wildan kepada para jamaahnya karena suatu perusahaan atau lembaga dapat hidup terus menerus tergantung pada pengguna jasa lembaga tersebut.

Pengurus KBIH Bustanul Wildan dapat membantu para calon jamaah haji untuk memenuhi semua persyaratan para calon jamaah, baik yang akan berangkat haji maupun umroh. Hal ini dilakukan oleh KBIH Bustanul Wildan agar para calon jamaah yang belum mendaftarkan diri segera terdaftar sebagai calon haji meskipun tidak dapat berangkat pada tahun tersebut. Selain itu, keterbukaan antara pihak pengelola dan calon jamaah haji sangat diperhatikan oleh semua pengurus atau pengelola yang bersangkutan, sehingga terjalin kepercayaan diantara kedua belah pihak; 2) Mempertemukan calon jamaah haji dengan pihak Bank, Salah satu keterbukaan yang dilakukan oleh KBIH Bustanul Wildan ini adalah mempertemukan pihak Bank dengan calon jamaah haji, sehingga para calon jamaah mengetahui setiap proses pendaftaran haji. Pemberian pelayanan yang baik kepada jamaah bukan merupakan suatu hal yang mudah, mengingat banyaknya kendala yang akan dihadapi. Akan tetapi, KBIH Bustanul Wildan ini mampu memberikan pelayanan yang optimal kepada para jamaahnya.

Sebagaimana Menurut Philip Kottler, "Pelayanan diartikan sebagai suatu aktivitas yang bermanfaat yang diberikan oleh satu atau beberapa pihak kepada pihak lain untuk dapat memuaskan kebutuhan dan keinginan yang pada dasarnya bersifat baik terwujud dan tidak akan menimbulkan kepemilikan apapun kepada yang menerimanya (Kottler, 1994:446). Kemudian, upaya-upaya yang dilakukan oleh KBIH Bustanul Wildan tersebut juga merupakan bagian dari strategi lembaga dalam rangka mempertahankan agar mampu bersaing dengan lembaga haji yang lainnya.

Sebagai sebuah lembaga yang bergerak di bidang jasa, KBIH Bustanul Wildan tentunya memiliki program kegiatan yang diberikan kepada para jamaah. Program kegiatan yang disusun oleh KBIH Bustanul Wildan agar ada kejelasan informasi kegiatan yang akan dilaksanakan, adanya kejelesan program kegiatan sangat membantu dan memudahkan para pengurus dalam menjalankan proses bimbingan dan pelatihan. Program kegiatan tersebut diantaranya sebagai berikut: 1) Menentukan tempat dan cara penyelenggaraannya, karena Bimbingan manasik haji untuk para calon jamaah haji yang terdaftar di KBIH Bustanul Wildan dilakukan di lapangan, yaitu lapangan yang berdekatan dengan kantor sebagai tempat pemberian materi manasik dan melaksanakan praktek manasik haji.

Selain manasik haji dilaksanakan di KBIH Bustanul Wildan, manasik juga dilaksanakan di tempat yang telah ditentukan oleh pemerintah yaitu pada manasik 
gabungan yang diikuti oleh semua calon jamaah haji yang ada di kabupaten Bandung ; 2) Menentukan waktu pelaksanaan manasik, yaitu Manasik dilaksanakan 2 kali pertemuan dalam setiap bulannya, yaitu pada minggu ke satu dan minggu ke tiga dan dilaksanakan selama delapan bulan sebelum pemberangkatan. Kemudian pada setiap pertemuan dialokasikan waktu sekitar kurang lebih satu 75 menit untuk materi, dan dilanjutkan kurang lebih sekitar 45 menit untuk membaca doa-doa yang ada dalam materi manasik. 3) Program Bimbingan, yaitu terdiri dari pemberian materi dan latihan / simulasi pelaksanaan proses ibadah haji.

\section{Faktor Pendukung dan Penghambat dalam Pelayanan Bimbingan Manasik Haji KBIH Bustanul Wildan}

KBIH Bustanul Wildan merupakan lembaga yang memberikan fasilitas bimbingan dan pelayanan ibadah haji kepada calon jamaah haji. Sebagaimana menurut Atep Adya Brata, bahwa pelayanan yang baik adalah adalah "segala usaha penyediaan fasilitas dalam rangka mewujudkan kepuasan para calon pembeli atau pelanggan sebelum dan sesudah terjadinya transaksi (Brata, 1999:93).

Dalam pelaksanaan pelayanan terdapat beberapa faktor pendukung dan penghambat berjalannya kinerja KBIH Bustanul Wildan dalam mencapai tujuan secara efektif.

Adapun faktor pendukung dan penghambat implementasi fungsi manajemen dalam pelayanan bimbingan manasik haji sebagai berikut: 1) Faktor Pendukung diantaranya: (a) Sarana prasarana kantor KBIH Bustanul Wildan mempunyai sekertariat sendiri meskipun satu tempat dengan Pondok Pesantren Bustanul Wildan. KBIH Bustanul Wildan sudah memiliki kantor yang lokasinya strategis dan mudah dijangkau berada dipinggiran kota satu lokasi dengan Pondok Pesantren Bustanul Wildan Jl. Tanjakansari No. 24 Cileunyi Bandung. Didukung dengan sarana prasarana yang memadai dengan cara pemberian materi dengan menggunakan laptop, monitor, LCD, dan auditoriumnya dilengkapi dengan sound system, sehingga mempermudah pelayanan bimbingan manasik haji; (b) Sumber Daya Pembimbing dan Karyawan yang Profesional dan berpengalaman Pembimbing dan karyawan di KBIH Bustanul Wildan sudah professional dan berpengalaman.Maka sudah mempunyai bekal dan kemampuan dalam membimbing dan melayani yang baik pada saat di tanah air maupun di tanah suci.pembimbing memiliki tanggung jawab yang ditanggung demi pengelolaan lembaga KBIH yang nantinya dalam melayani pembimbingan kepada jamaah bisa berjalan dengan baik dan lancar; (c) Dana untuk meningkatkan pelayanan jamaah, KBIH Bustanul Wildan mempunyai dana sendiri untuk meningkatkan pelayanan jamaah dengan melengkapi sarana dan prasarana untuk kelengkapan kantor, jamaah dan juga untuk pembimbing yang berangkat ke tanah suci untuk membimbing para jamaah haji; (d) Adanya kerjasama antara pengurus dan pengurus yang sebagian besar adalah keluarga pendiri KBIH Bustanul Wildan, juga terjalinnya hubungan yang baik antara para pengurus dan jamaah sebagai pengguna jasa; (e) Dukungan instansi pemerintah, Pihak pemerintah juga 
mendukung pelayanan KBIH Bustanul Wildan, karena KBIH Bustanul Wildan adalah mitra kerja pemerintah yang dapat mewujudkan lembaga dalam memberikan pelayanan kepada jamaah haji agar merasa aman dan nyaman. 2) Faktor Penghambat, KBIH Bustanul Wildan sejak awal pembimbingan pada tahun 2000 sampai sekarang masih terdapat hambatan dalam memberikan pelayanan yang dihadapi KBIH ini. Adapun faktor penghambat yang mengganggu jalannya pelayanan jamaah haji antara lain: (a) Tingkat kedisiplinan pengurus, karena kesibukan para pengurus KBIH Bustanul Wildan, kurangnya tanggung jawab satu dengan yang lain; (b) Keputusan pemerintah yang sangat berubah dari tahun ke tahun, sehingga pihak KBIH harus menunggu sampai ada kebijakan baru tersebut; (c) Adanya jamaah yang masih malu bertanya langsung kepada para pengurus, meski pihak KBIH telah terbuka kepada jamaah; (d) Faktor usia yang berbeda-beda menyebabkan hambatan dalam pelayanan. Faktor usia jamaah yang lanjut usia sangat mempengaruhi pembimbing dalam memberikan pelayanan sehingga pembimbing bertanggung jawab secara penuh. Kesulitan pengurus dan pembimbing terletak dalam memberikan informasi kepada jamaah yang rumahnya jauh dan sulit untuk dijangkau.

Proses untuk mencapai pelayanan yang baik telah dilakukan oleh $\mathrm{KBIH}$ Bustanul Wildan, yaitu melalui sarana dan pra sarana yang digunakan di KBIH Bustanul Wildan. Hal ini dilakukan agar para calon jamaah haji dapat melaksanakan serangkaian proses ibadah haji di tanah suci dengan baik, dan tidak canggung ketika dihadapkan pada ibadah yang nyata, yakni ketika sudah di tanah suci. faktor sarana pelayanan ini sangat berpengaruh pada upaya yang dilakukan oleh KBIH Bustanul Wildan dalam memberikan pelayanan yang baik, yaitu dapat memberikan rasa nyaman bagi orang-orang yang berkepentingan serta dapat menimbulkan perasaan puas pada orang-orang yang berkepentingan dalam hal ini adalah para pengguna jasa KBIH Bustanul Wildan (calon jamaah haji).

Selintas pelaksanaan KBIH Bustanul Wildan ini biasa saja, namun penulis melihat KBIH Bustanul Wildan ini mempunyai peluang yang sangat besar untuk mampu bersaing dengan lembaga haji yang lain. Lembaga ini mempunyai tempat yang sangat startegis, mempunyai banyak santri yang bisa dilibatkan dalam proses penyebaran informasi mengenai KBIH Bustanul Wildan.

Selain itu, bentuk keberhasilan yang telah dicapai oleh KBIH Bustanul Wildan ini diperoleh dari pelayanan para pengurus KBIH Bustanul Wildan yang cenderung terbuka kepada para calon jamaah haji. Salah satu pelayanan yang sangat baik diterima oleh para calon jamaah haji adalah kesiapan KBIH membimbing para calon jamaah haji dari mulai pendaftaran, bimbingan manasik, pemberangkatan hingga pemulangan kembali ke tanah air. Kemudian dalam proses manasik haji, KBIH Bustanul Wildan juga sangat terbuka bagi para calon haji yang ingin mengikuti serangkaian proses manasik haji, meskipun calon haji tersebut tidak akan berangkat pada tahun yang bersangkutan.

Selain itu, salah satu bentuk kesuksesan yang telah diperoleh $\mathrm{KBIH}$ Bustanul Wildan adalah banyaknya para calon jamaah haji yang mendaftarkan diri 
Implementasi Fungsi Manajemen dan Pelayanan Manasik ...

untuk bergabung dan melakukan bimbingan di KBIH Bustanul Wildan.keberhasilan yang dicapai oleh KBIH Bustanul Wildan tidak terlepas dari peran para pengurus didalamnya, yaitu ketua umum KBIH Bustanul Wildan, para pengurus, dan para pembimbing yang terlibat didalamnya.

Hal ini memberikan penilaian tersendiri bagi KBIH Bustanul Wildan, karena lembaga ini telah memberikan pelayanan yang baik kepada calon jamaah haji yang bergabung di KBIH tersebut. Sehingga pada saat ini KBIH Bustanul Wildan sangat berkesan untuk para calon jamaah haji.

Bukanlah hal yang mudah untuk mampu mendapatkan kepercayaan dari hal layak, tetapi dengan program yang dimiliki dan ditawarkan KBIH Bustanul Wildan, lembaga ini mampu memberikan pelayanan yang dirasa puas oleh para pengguna jasa (calon jamaah haji). Dengan demikian, KBIH Bustanul Wildan sadar akan pelayanan sebagai proses pemenuhan kebutuhan melalui aktivitas orang lain secara langsung, merupakan konsep yang senantiasa aktual dalam berbagai aspek kelembagaan, sehingga dalam perjalanannya, KBIH Bustanul Wildan akan terus berusaha untuk memberikan pelayanan yang baik terhadap jamaah haji.

\section{PENUTUP}

Dalam setiap pelayanan bimbingan ibadah haji, KBIH Bustanul Wildan selalu menerapkan fungsi-fungsi manajemen, meskipun di dalam penerapannya masih kurang maksimal, berikut kesimpulan implementasi fungsi-fungsi manajemen dalam pelayanan bimbingan manasik haji di Kelompok Bimbingan Ibadah Haji (KBIH) Bustanul Wildan: pertama, implementasi fungsi manajemen dalam pelayanan bimbingan manasik pada calon jamaah haji di KBIH Bustanul Wildan memenuhi fungsi manajemen berdasarkan pendapat GR. Terry yaitu Planning, Organizing, Actuating, dan Controlling (Hasibuan, 2001:38).

Implementasi dalam perencanaan yaitu KBIH Bustanul Wildan membuat perencanaan dalam proses perekrutan, bimbingan di tanah air, bimbingan di tanah suci, dan bimbingan pasca ibadah haji. Salah satu bentuk dari perencanaanya yaitu membuat agenda kegiatan manasik yang akan dilakukan oleh calon jamaah haji.

Implementasi dalam pengorganisasian, KBIH Bustanul Wildan membuat struktur kepengurusan sesuai bidangnya masing-masing namun terkadang kepengurusan tidak berjalan sesuai tugasnya masing-masing karena pimpinan melaksanakan tugas-tugas KBIH sendiri. Perencanaan yang telah dibuat kemudian diimplementasikan dalam fungsi yang ke-3 yaitu penggerakan, apa yang telah direncanakan sebelumnya kemudian dilaksanakan terkadang dalam pelaksanaan tidak sesuai dengan apa yang direncanakan karena tedapat beberapa kendala. kedua, Dalam pelaksanaan pelayanan, upaya yang dilakukan oleh pihak KBIH Bustanul Wildan telah memberikan pelayanan yang baik bagi para jamaah dan dapat memuaskan para jamaah dengan cara melayani setiap calon jamaah haji dalam pengurusan semua administrasi yang berkaitan dengan pelaksanaan ibadah haji dan umroh, berusaha terbuka dalam setiap proses pendaftaran haji dengan 
Iseu Susilawati, Ahmad Sarbini, \& Asep Iwan Setiawan

cara mempertemukan jamaah dengan bank, memberikan bimbingan manasik, dan menentukan jadwal bimbingan manasik haji; ketiga, KBIH Bustanul Wildan tidak lepas dari faktor pendukung dan faktor penghambat. Faktor kesadaran dari setiap pengurus yang terlibat dalam pelaksanaan pelayanan di KBIH Bustanul Wildan memiliki peranan yang penting dalam setiap pelaksanaan kegiatan di $\mathrm{KBIH}$ Bustanul Wildan, karena dengan keasadaran tersebut para pengurus yang terlibat mampu bekerjasama, sehingga tercipta komunikasi yang baik di lingkungan organisasi dan berdampak positif pada pelayanan yang dilakukan. Sedangkan faktor penghambat yang terjadi bukanlah menjadi penghambat yang berarti bagi KBIH Bustanul Wildan. Dengan demikian, KBIH Bustanul Wildan dapat terus memberikan pelayanan yang baik kepada jamaah.

\section{DAFTAR PUSTAKA}

Badrudin. (2013). Dasar-Dasar Manajemen, Bandung: Alfabeta.

Brantas. (2009). Dasar-Dasar Manajemen, Bandung: Alfabeta.

Brata, Atep Adya. 1999. Bisnis dan Hukum Perdata Dasar SMK. Armico: Bandung.

Casson, N. H. (1981). Petunjuk Praktis Dalam Berusaha, Surabaya: Usaha Nasional.

Choliq, A. (2011). Pengantar Manajemen, Semarang: Rafi Sarana Perkasa.

Chols, dkk. (1996). Kamus Inggris Indonesia. Jakarta: Gramedia.

Fatoni, U. (2014) Respon Da’i terhadap Gerakan Jemaat Ahmadiyah Indonesia

(JAI) di Tenjowaringin Tasikmalaya. Jurnal Dakwah 15 (1), 49-65

Hasibuan, S.P. (2001). Manajemen Dasar, Pengertian dan Masalah, Jakarta: Bumi Aksara

Herbert, N. C. (1981). Petunjuk Praktis Dalam Berusaha, Surabaya: Usaha Nasional. Kadarman, A.M. (1994). Pengantar Ilmu Manajemen, Jakarta: Gramedia Pustaka Utama.

Manullang, M. (1974). Management Personalia, Jakarta: Aksara Baru.

Moleong, L. (2004). Metodologi Penelitian Kualitatif, Bandung: Rosda Karya

Muchtarom, Z. (1996). Dasar-dasar Manajemen Dakwah, Yogyakarta: Al-Amin Press.

Mulyono, E. dan Rofi'ie, A. H. (2013). Panduan Praktis dan Terlengkap Ibadah Haji dan Umroh. Trans Media: Jakarta

Setiawan, A. I. (2011). Efektivitas Dakwah Fiah: Studi Model Dakwah pada Lembaga Dakwah Kampus. Ilmu Dakwah: Academic Journal for Homiletic Studies, 5(18), 541-574.

Setiawan, A. I. (2015). Budaya Organisasi dalam Lembaga Islam, UIN Sunan Gunung Djati: ANIDA, 1-15

Siagian, P. S. (1989). Fungsi-fungsi Manajerial, Jakarta: Bina Aksara.

Terry, R. G. (1990). Prinsip-Prinsip Manajemen, Jakarta: Bumi Aksara.

Usman, H. (2005). Evaluasi Kinerja Perusahaan, Jakarta: PT. Gramedia Pustaka Utama. 